\title{
ANALYSIS OF PRECIPITATES IN ALUMINIUM ALLOYS WITH THE USE OF HIGH-RESOLUTION ELECTRON MICROSCOPY AND COMPUTER SIMULATION
}

\author{
RAZISKAVE OBORIN V ALUMINIJEVIH ZLITINAH Z \\ VISOKORESOLUCIJSKO ELEKTRONSKO MIKROSKOPIJO IN \\ RAČUNALNIŠKO SIMULACIJO
}

\author{
Krzysztof Matus, Anna Tomiczek, Klaudiusz Gołombek, Mirosława Pawlyta \\ Silesian University of Technology, Institute of Engineering Materials and Biomaterials, 18A Konarskiego Str., \\ 44100 Gliwice, Poland \\ krzysztof.matus@polsl.pl \\ Prejem rokopisa - received: 2016-07-27; sprejem za objavo - accepted for publication: 2017-01-27
}

doi:10.17222/mit.2016.226

\begin{abstract}
This paper presents the results of the tests using high-resolution transmission electron microscopy (HRTEM) with both transmission and scanning modes, as well as energy-dispersive-spectroscopy (EDS) investigation of the AlSi9Cu alloy after laser surface remelting. The possibility of using a computer simulation to identify precipitates in the analysed alloy was also explored. The obtained results and computer simulations were compared. Moreover, this article presents the advantages of the computer aid in solving the diffraction patterns and precipitates in supercell simulations.

Keywords: precipitation, crystallography, TEM, computer simulations

$\mathrm{V}$ prispevku so predstavljeni rezultati preiskave $\mathrm{AlSi} 9 \mathrm{Cu}$ zlitine z laserskim pretaljevanjem površin z uporabo transmisijske elektronske mikroskopije z visoko ločljivostjo (angl. HRTEM) na dva načina: s transmisijskim skeniranjem, kot tudi z energijsko disperzijsko spektroskopijo (angl. EDS). Z uporabo računalniške simulacije je bila preiskana možnost identifikacije delcev v analizirani zlitini. Dobljeni rezultati in računalniške simulacije so bili primerjani. Poleg tega članek predstavlja prednosti računalniške simulacije pri študiji vzorcev difrakcije in oborin v posameznih stanjih celic.

Ključne besede: oborine, kristalografija, TEM, računalniške simulacije
\end{abstract}

\section{INTRODUCTION}

Aluminium alloys are the most widely used alloys in modern technology, mainly due to high specific strength and low density. Other factors behind the widespread distribution of aluminium alloys are their excellent electrical conductivity and high corrosion resistance..$^{1,2}$ The use of laser surface treatment to improve the utility properties of aluminium alloys allows the remelting of the surface layer of the material or its enrichment with alloy elements. The remelting of the material surface and rapid crystallisation allow an improvement of the mechanical properties of alloys, mainly in the field of abrasion resistance and tribological properties of the surface. Through the generation of plenty of fine precipitates, the strength is increased as well. The influence of alloying element precipitates on aluminium alloys is a complex issue and it is still one of the most promising topics in materials science. ${ }^{3-7}$

Laser surface treatment ensures that the processed material obtains new properties due to the rapid dispersion of the heat from the melted zone. This phenomenon enables the crystallisation of very fine precipitates to occur. Laser remelting can be used for small and large elements. The most common alloyed layers have a thickness from $0.33 \mathrm{~mm}$ to about $3 \mathrm{~mm}$. A layer formed by remelting usually has a high homogeneity as well as a fine crystalline structure. The use of the laser technology makes it possible to obtain surface layers with high contents of alloying elements and a unique combination of elements that conventional alloys rarely contain. ${ }^{8-11}$

Generally, the laser surface treatment is accomplished with two methods, which differ from one another based on how the alloying addition is introduced to the surface layer (which is schematically presented in Figure 1). When the surface of a material is subjected to a laser beam and then melted, the process is called remelting (Figure 1a). When an alloying material is applied to a surface and then melted with a laser beam (most of the materials are added in the forms of tapes, pastes or powders), the process is called alloying (Figure 1b). ${ }^{12,13}$

This article aims to identify the precipitates in an aluminium alloy after the laser treatment using transmission electron microscopy and computer simulations.

\section{EXPERIMENTAL PART}

For the experimental procedure, cast $\mathrm{AlSi} 9 \mathrm{Cu}$ aluminium alloy was used. Its average chemical composition is shown in Table 1. This alloy was subjected to 
K. MATUS et al.: ANALYSIS OF PRECIPITATES IN ALUMINIUM ALLOYS WITH THE USE OF HIGH-RESOLUTION ...
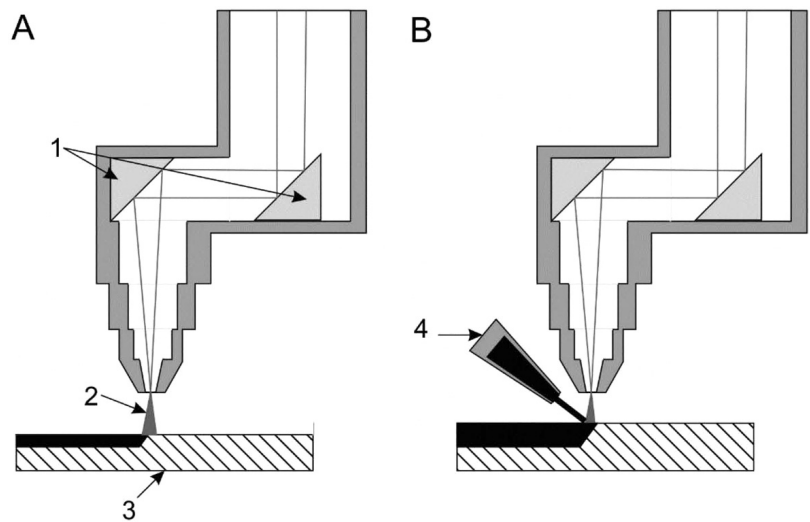

Figure 1: Diagram of laser treatment: a) remelting, b) alloying ${ }^{12,13}$

remelting using high-power diode laser (HPDL) ROFIN SINAR DL 020 with a radiation wavelength of $940 \pm 5$ $\mathrm{nm}$ and a laser power of $2 \mathrm{~kW}$ with a spot size of $1.8 \mathrm{~mm} \times 6.8 \mathrm{~mm}$ and argon as the shielding gas.

Table 1: Chemical composition of AlSi9Cu alloy, in mass fractions $(w / \%)$

\begin{tabular}{|c|c|c|c|c|c|c|}
\hline $\mathrm{Si}$ & $\mathrm{Cu}$ & $\mathrm{Fe}$ & $\mathrm{Mn}$ & $\mathrm{Mg}$ & $\mathrm{Ti}$ & $\mathrm{Al}$ \\
\hline 9.0 & 1.0 & 0.7 & 0.4 & 0.3 & 0.3 & balance \\
\hline
\end{tabular}

Samples for transmission-electron-microscopy (TEM) observations were prepared as thin foils, where the Gatan PIPS 691 precision ion polishing system was used to prepare them. Studies were carried out using a scanning transmission electron microscope S/TEM Titan 80-300 type (FEI, USA), operated at $300 \mathrm{kV}$ and equipped with a EDAX Li-drifted Si EDS detector (Philips Electronic Instruments Corp. PV97-61850 ME). Electron-microscopy observations were performed with a probe Cs-corrected S/TEM Titan 80-300 FEI microscope, equipped with an EDAX EDS detector (energy resolution of $132 \mathrm{eV})$. HRTEM images $(300 \mathrm{kV}, \mathrm{Cs}=1.2$ $\mathrm{mm}, 0.2 \mathrm{~nm}$ point resolution) were recorded using only a condenser lens aperture, and thus without an objective lens aperture. HAADF-STEM images were obtained

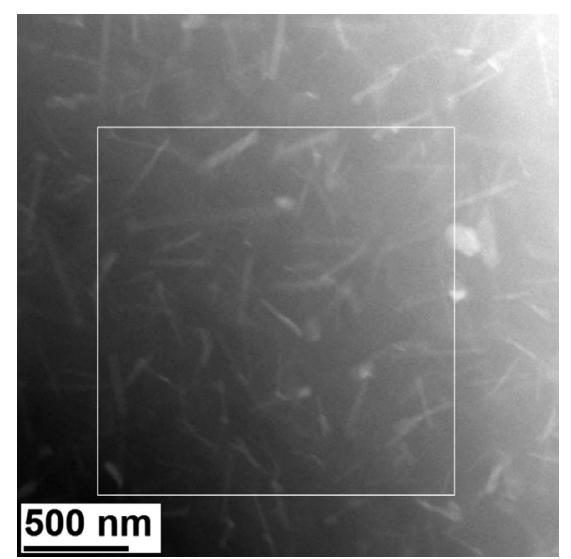

Figure 2: STEM-HAADF image of titanium precipitates in an aluminium-alloy matrix with a HAADF STEM detector (Model Fischione 3000). A convergence angle of $0.974^{\circ}$ was used with the HAADF detector's inner collection angle of $5.443^{\circ}$. The probe size used was about $0.1 \mathrm{~nm}$. The diffraction patterns were collected by exploiting both the selected area electron diffraction (SAED) and Fourier transformations from HRTEM and HAADF images. Chemical-composition examinations were carried out using energy-dispersive spectroscopy (EDS) for the identification of the precipitates which occurred in the samples. To perform a simulation of unit cells, the CrystalMaker software was used. ${ }^{14}$ The simulation of supercells and the results of electron diffraction were realised with the software "Química de Solidos y Catalisis, Estructura y Química de Nanomateriales" developed at the University of Cadiz. ${ }^{15,16}$

\section{RESULTS AND DISCUSSION}

Despite a low content of titanium in the analysed material (0.3\%, Table 1), microscopic observations revealed the presence and dense occurrence of titanium nanoprecipitates in the shape of sticks, sized approximately $250 \mathrm{~nm} \times 50 \mathrm{~nm}$ (Figures 2 and 3). The reason for this is the fact that it is a high-melting-point element. At the time of the laser alloying, the volume of the material was treated with a laser beam and then rapidly melted and cooled down. When lowering the temperature, the precipitates of titanium were the first to crystallize. After melting all the elements, including titanium, there was an even distribution. The amount of titanium is limited, so the size of the crystallites formed did not exceed $250 \mathrm{~nm}$. The boundary between the matrix and the titanium precipitates is a favorable nucleation area for the other precipitates to grow on titanium rods. The EDS map presents the titanium distribution and determines the localization of titanium precipitates in the aluminium matrix (Figure 3).

Figure 4 shows an enlarged view of one of the precipitates containing Ti. The size of the precipitate is

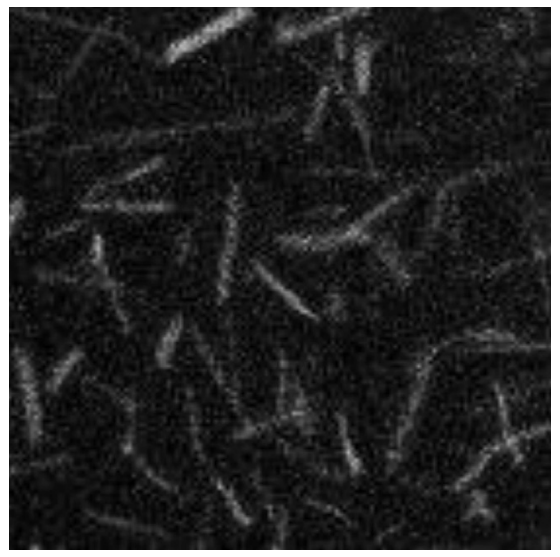

Figure 3: STEM-HAADF/EDS map which presents a magnification of the area from Figure 2 and shows the distribution of titanium in the aluminium matrix 


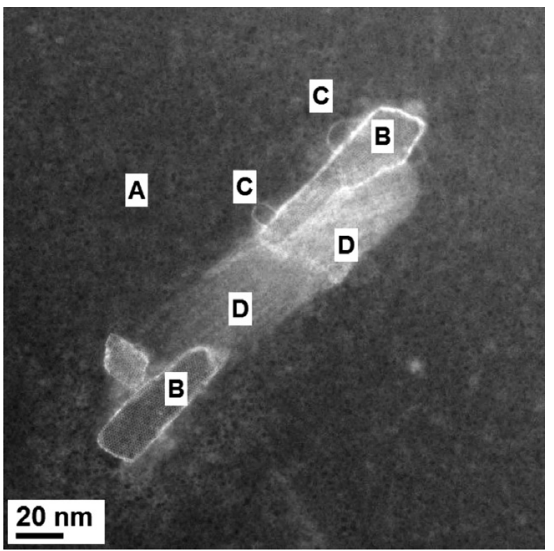

Figure 4: STEM-HAADF image of a complex precipitate in the aluminium matrix

approximately $150 \mathrm{~nm} \times 30 \mathrm{~nm}$. The contrast in the STEM-HAADF image indicates a difference in the chemical composition between the precipitate and the matrix. The matrix area and three areas characterised by differing contrasts (different chemical compositions) and structures (different phases) are marked by A and B-D, respectively. The results of the chemical analysis of the selected areas are presented in Figure 5, in graphs A-D, and Table 2.

Table 2: Chemical compositions of the areas marked with letters A-D in Figure 5 (in amount fractions, $a / \%$ )

\begin{tabular}{|l|c|c|c|c|c|}
\hline & $\mathrm{Al}(\mathrm{K})$ & $\mathrm{Cu}(\mathrm{K})$ & $\mathrm{Mg}(\mathrm{K})$ & $\mathrm{Si}(\mathrm{K})$ & $\mathrm{Ti}(\mathrm{K})$ \\
\hline point A & 93.95 & 6.04 & - & - & - \\
\hline point B & 18.92 & 15.04 & 39.83 & 26.19 & - \\
\hline point C & 67.65 & 5.03 & 3.70 & 23.60 & - \\
\hline point D & 75.64 & 6.35 & - & 5.75 & 12.24 \\
\hline
\end{tabular}

In the centre of Figure 4, the precipitate marked with symbol $\mathrm{D}$, which contains mainly $\mathrm{Ti}, \mathrm{Al}$ and $\mathrm{Si}$, is shown. The observed precipitate had an irregular, elongated shape and a size of approximately $100 \mathrm{~nm} \times 20 \mathrm{~nm}$. The grain boundary between the precipitate with titanium and the matrix served as the nucleation point for the other precipitates. Copper results were affected by a holder and by the pole pieces, which were made of copper. There were at least two other types of precipitates, which were marked with symbols $\mathrm{B}$ and $\mathrm{C}$. The phase marked as $\mathrm{B}$ consisted of $\mathrm{Al}, \mathrm{Mg}, \mathrm{Si}$ and $\mathrm{Cu}$ (Figure 5b). The intensities of the $\mathrm{Mg}, \mathrm{Si}$ and $\mathrm{Cu}$ peaks (K lines) were higher than that of the matrix. At the phase boundary between the aluminium matrix and the precipitate marked as B, two smaller precipitates, marked as $\mathrm{C}$, can be noticed. The chemical composition of precipitate $\mathrm{C}$ was similar to that of precipitate $\mathrm{B}(\mathrm{Al}$, $\mathrm{Si}, \mathrm{Mg}$ and $\mathrm{Cu}$ ), as shown in Figure 5c, but the relative intensities of the peaks were different. Detected $\mathrm{Mg}$ content in precipitate $\mathrm{C}$ was practically at the background level. A fast Fourier transform (FFT) of the precipitate marked with the letter $\mathrm{B}$ is presented in Figure 6a. Compared to the EDS spectrum, the measurement of the spacings and angles in the FFT, with its high-resolution image, and a computer simulation of the diffraction pattern allow the identification of the precipitate marked with letter B as the Q phase (with a chemical composition close to $\mathrm{A} 13 \mathrm{Cu} 2 \mathrm{Mg} 9 \mathrm{Si} 7$ ). A comparison of the simulated electron diffraction and the experimental one allows determining the orientation of the Q-phase precipitate as [001] (Figure 6b).

The unit cell of the $\mathrm{Q}$ phase was simulated along the [001] direction (Figure 7). This data was necessary to create a supercell in the Q phase (Figure 8a) with its characteristic arrangement of atoms and marked regular shape between the copper atoms. This was then adapted to an enlarged HAADF image of the investigated precipitate (Figure 8b). The HAADF detector enabled the
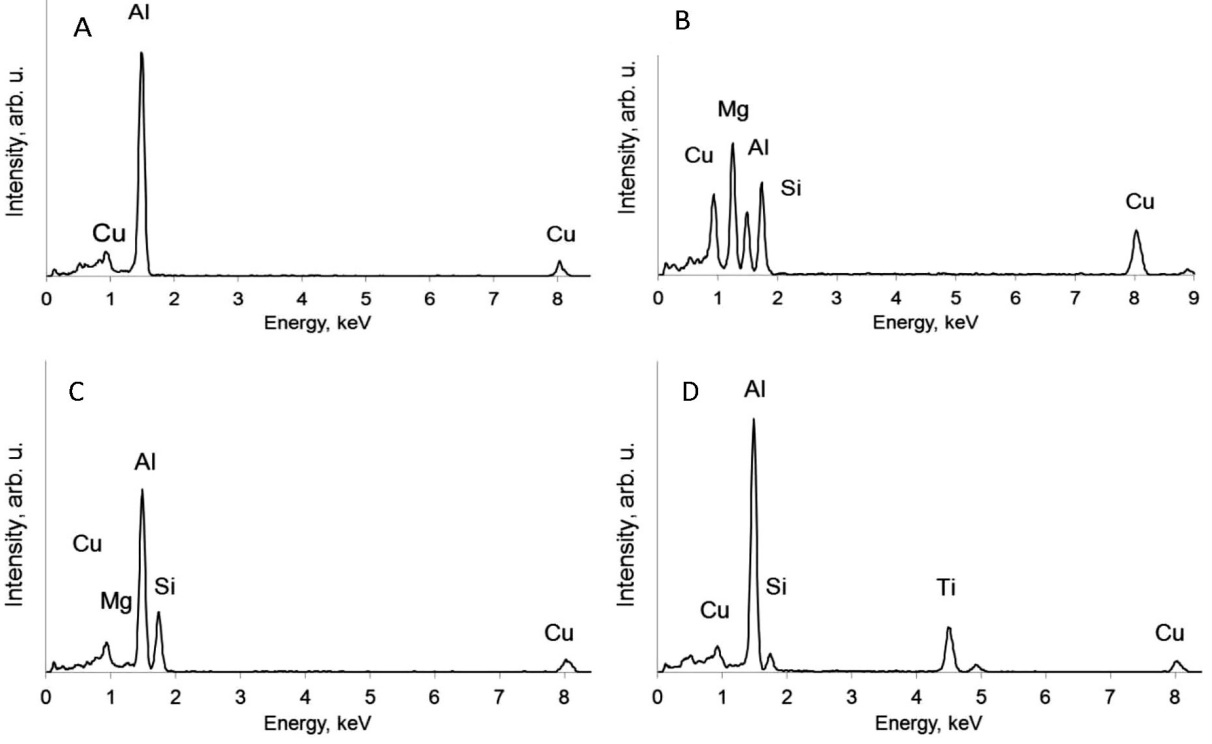

Figure 5: Results of the chemical analysis of the areas marked with letters A-D in Figure 5 


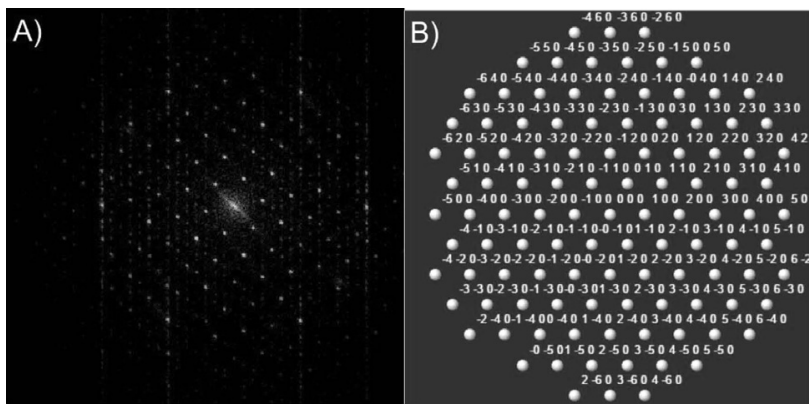

Figure 6: a) Fast Fourier transform (FFT) of a high-resolution image and b) simulation of the diffraction pattern of the Q-phase precipitate in the [001] direction

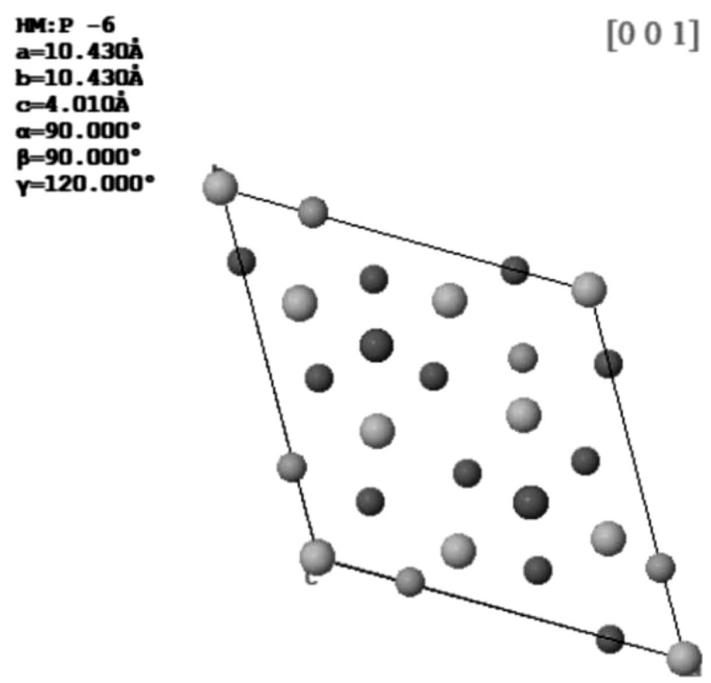

Figure 7: Unit cell of precipitate Q in the [001] direction

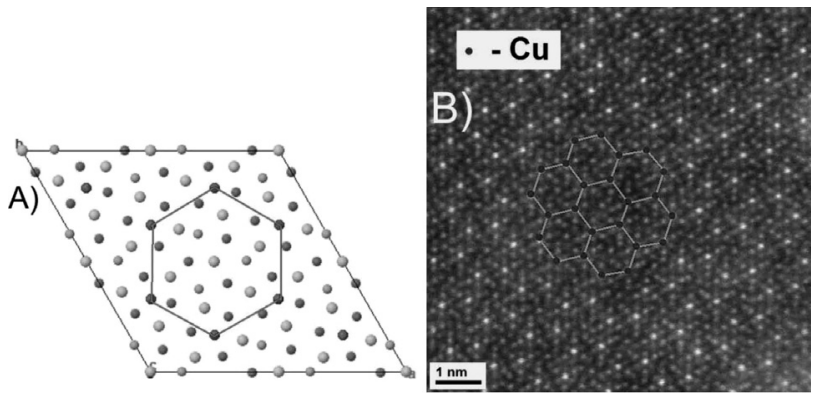

Figure 8: a) Q-phase supercell with the selected pattern of copper atoms and $b$ ) this pattern registered on the HAADF image

distinction and contrast between the columns of atoms containing elements of differentiated value $Z$. Images were obtained by recording the intensity of the scattered electrons as a function of the incident beam position on the sample surface. $\mathrm{Cu}$ has the highest value of $Z$, therefore the copper atoms were characterized as having the best contrast, or the brightest points.

Using the same method, the area marked as $\mathrm{C}$ in Figure 4 was identified as the U1 phase $\left(\mathrm{MgAl}_{2} \mathrm{Si}_{2}\right)$, and area $\mathrm{D}$ was determined as the $\mathrm{TiAl}_{3}$ phase. ${ }^{17,18}$

The precipitates created during the laser remelting of aluminium alloys have very complex chemical compo- sitions and crystallographic structures (Figures 5 and $\mathbf{7}$ and Table 2). The interface between the matrix and the large amount of precipitation is a unique place to increase further the creation of the precipitates, which are successfully identified as the participations of the complex U1 and Q phases. Particularly the precipitates of the $\mathrm{Q}$ phase, which is a major equilibrium phase of the $\mathrm{Al}-\mathrm{Mg}-\mathrm{Si}-\mathrm{Cu}$ system, are noteworthy. The $\mathrm{Q}$ phase belongs to the P-6 space group with lattice parameters: $a=b=0.1039 \mathrm{~nm}, c=0.409 \mathrm{~nm}$, and $\alpha=\beta=90^{\circ}, \gamma=$ $120^{\circ} \cdot .^{17}$

\section{CONCLUSIONS}

Laser surface treatment, due to its requirement for a large amount of energy, leads to a dissolution of the surface layers of alloys due to a rapid dissipation of heat into the interior of the material. This causes the remelted material to solidify very quickly, resulting in the formation of fine precipitates of high-melting elements, which are unique places for the nucleation of other precipitates. This type of treatment can increase the hardness due to the refinement of the microstructure. The completed research determined that the phase that forms first during the cooling was $\mathrm{TiAl}_{3}$, on which other precipitates with complex chemical compositions such as the precipitates of the Q and U1 phases grew. With the help of the computer simulations allowing the identification of the phases of the process, the process was shortened in comparison to the research using the databases on a computer. Moreover, the use of simulation software to obtain diffraction patterns simplified the processes of identifying the phases and their orientations. The simulation of unit cells and supercells allowed the matching of the simulated phases with their high-resolution images.

\section{Acknowledgment}

This publication was financed by the Ministry of Science and Higher Education of Poland as the statutory financial grant of the Faculty of Mechanical Engineering, SUT.

\section{REFERENCES}

${ }^{1}$ C. Cayron, P. A. Buffat, Transmission electron microscopy study of the $\beta$ ' phase (Al-Mg-Si alloys) and $\mathrm{QC}$ phase (Al-Cu-Mg-Si alloys): ordering mechanism and crystallographic structure, Acta Mater., 48 (2000), 2639-2653, doi:10.1016/S1359-6454(00)00057-4 ${ }^{2}$ D. J. Chakrabarti, D. E. Laughlin, Phase relations and precipitation in $\mathrm{Al}-\mathrm{Mg}-\mathrm{Si}$ alloys with $\mathrm{Cu}$ additions, Prog. Mater. Sci., 49 (2004), 389-410, doi:10.1016/S0079-6425(03)00031-8

${ }^{3}$ A. L. Garcia-Garcia, I. Dominguez-Lopez, L. Lopez-Jimenez, J. D. O. Barceinas-Sanchez, Comparative quantification and statistical analysis of $\eta$ ' and $\eta$ precipitates in aluminum alloy AA7075-T651 by TEM and AFM, Mater. Charact., 87 (2014), 116-124, doi:10.1016/ j.matchar.2013.11.007 


\section{MATERIALI IN TEHNOLOGIJE/MATERIALS AND TECHNOLOGY (1967-2017) - 50 LET/50 YEARS}

\section{K. MATUS et al.: ANALYSIS OF PRECIPITATES IN ALUMINIUM ALLOYS WITH THE USE OF HIGH-RESOLUTION ...}

${ }^{4}$ N. K. Mukhopadhyay, H. J. Chang, J. Y. Lee, D. H. Kim, Electron microscopy of an icosahedral phase in a rapidly solidified A118Mg3Mn2 complex metallic alloy, Scr. Mater., 59 (2008), 1119-1122, doi:10.1016/j.scriptamat.2008.07.024

${ }^{5}$ A. Biswas, D. J. Siegel, D. N. Seidman, Compositional evolution of Q-phase precipitates in an aluminum alloy, Acta Mater., 75 (2014), 322-336, doi:10.1016/j.actamat.2014.05.001

${ }^{6}$ F. Delmas, M. J. Casanove, P. Lours, A. Couret, A. Coujou, Quantitative TEM study of the precipitation microstructure in aluminium alloy $\mathrm{Al}(\mathrm{MgSiCu}) 6056 \mathrm{~T} 6$, Mater. Sci. Eng. A, 373 (2004), doi:10.1016/j.msea.2003.12.068

${ }^{7}$ W. Yang, S. Ji, M. Wang, Z. Li, Precipitation behaviour of Al-Zn$\mathrm{Mg}-\mathrm{Cu}$ alloy and diffraction analysis from $\eta$ ' precipitates in four variants, J. Alloys Compounds, 610 (2014), 623-629, doi:10.1016/ j.jallcom.2014.05.061

${ }^{8}$ Z. Hu, L. Wan, S. Wu, H. Wu, X. Liu, Microstructure and mechanical properties of high strength die-casting $\mathrm{Al}-\mathrm{Mg}-\mathrm{Si}-\mathrm{Mn}$ alloy, Mater. Des., 46 (2013), 451-456, doi:10.1016/j.matdes.2012.10.020

${ }^{9}$ J. Aguilar, M. Fehlbier, A. Ludwig, A. Bührig-Polaczek, P. R. Sahm, Non-equilibrium globular microstructure suitable for semisolid casting of light metal alloys by rapid slug cooling technology (RSCT), Mater. Sci. Eng. A, 375-377 (2004), 651-655, doi:10.1016/ j.msea.2003.10.091

${ }^{10}$ W. M. Lee, M. A. Zikry, High strain-rate modeling of the interfacial effects of dispersed particles in high strength aluminum alloys, Int. J. Solids Struct., 49 (2012), 3291-3300, doi:10.1016/j.ijsolstr.2012. 07.003

${ }^{11}$ J. F. Nie, B. C. Muddle, On the form of the age-hardening response in high strength aluminium alloys, Mater. Sci. Eng. A, 319-321 (2001), 448-451, doi:10.1016/S0921-5093(01)01054-1
${ }^{12}$ J. C. Betts, Laser surface modification of aluminium and magnesium alloys, Surf. Eng. Light Alloys, Woodhead Publishing, 2010, 444-474, doi:10.1533/9781845699451.2.444

${ }^{13}$ H. C. Man, C. T. Kwok, T. M. Yue, Cavitation erosion and corrosion behaviour of laser surface alloyed MMC of SiC and Si3N4 on Al alloy AA6061, Surf. Coat. Technol., 132 (2000), 11-20, doi:10.1016/S0257-8972(00)00729-5

${ }^{14}$ http://www.crystalmaker.com

${ }^{15}$ C. López-Cartes, J. A. Pérez-Omil, J. M. Pintado, J. J. Calvino, Z. C. Kang, L. Eyring, Rare-earth oxides with fluorite-related structures: Their systematic investigation using HREM images, image simulations and electron diffraction pattern simulations, Ultramicroscopy 80 (1999), 19-39, doi:10.1016/S0304-3991(99)00067-4

${ }^{16}$ S. Bernal, F. J. Botana, J. J. Calvino, C. Lopez-Cartes, J. A. PerezOmil, J. M. Rodriguez-Izquierdo, The interpretation of HREM images of supported metal catalysts using image simulation: profile view images, Ultramicroscopy, 72 (1998), 135-164, doi:10.1016/ S0304-3991(98)00009-6

${ }^{17}$ R.-K. Pan, L. Ma, First-principles study on the elastic properties of B' and Q phase in Al-Mg-Si (-Cu) alloys, Phys. Scr., 87 (2013), doi:10.1088/0031-8949/87/01/015601

${ }^{18}$ S. J. Andersen, C. D. Marioara, R. Vissers, A. Frøseth, H. W. Zandbergen, The structural relation between precipitates in $\mathrm{Al}-\mathrm{Mg}-\mathrm{Si}$ alloys, the Al-matrix and diamond silicon, with emphasis on the trigonal phase U1-MgA12Si2, Mat. Sci. Eng. A - Struct., 444, (2007), 157-169, doi:10.1016/j.msea.2006.08.084 